Solid Earth Discuss., https://doi.org/10.5194/se-2017-60

Manuscript under review for journal Solid Earth

Discussion started: 26 July 2017

(c) Author(s) 2017. CC BY 4.0 License.

\title{
Formation and characteristics of an Ultisol in Peninsular Malaysia utilized for oil palm production
}

\author{
Arolu Ayanda Fatai ${ }^{1}$, Jusop Shamshuddin ${ }^{1}$, Che Ishaq Fauziah ${ }^{1}$, Othman Radziah $^{1}$ and \\ Mohsen Bohluli ${ }^{1}$ \\ ${ }^{1}$ Department of Land Management, Faculty of Agriculture, Universiti Putra Malaysia, 43400 \\ Serdang, Selangor, Malaysia \\ Correspondence to: J. Shamshuddin (shamshud@upm.edu.my)
}

Keywords: Acid soil, Oil palm, Soil fertility, Soil mineralogy, Ultisol

\begin{abstract}
Most of the soils in the upland areas of Peninsular Malaysia are classified as Ultisols. Oil palm production on these soils is usually limited by their inherent low soil productivity. However, the crop is cultivated successfully on most of the soils following right soil management practices. A study was conducted in Bera, Malaysia to determine the characteristics and fertility of an Ultisol cropped to oil palm for many years continuously. In this study, the soil in the plantation was sampled, analyzed and classified. The soil under study was formed under tropical environment with udic moisture regime on fine-grained sedimentary rocks mixed with tuffs of Permian age. Due to very long exposure to the condition of high temperature and high rainfall throughout its development, the soil in the area was reddish in color, clayey, deep and highly weathered. The study found that the clay fraction of the soil was dominated by kaolinite, hematite, goethite and gibbsite; hence, the CEC and basic cations were low. Besides, soil reaction was acidic in nature with soil $\mathrm{pH}$ slightly below 5 , but the exchangeable $\mathrm{Al}$ was more than $1 \mathrm{cmol}_{\mathcal{C}} / \mathrm{kg}$ soil. However, it was believed that these inherent characteristics were not expected to significantly affect the production of oil palm grown on the soil. With proper agronomic practices, the area can be utilized for oil palm production sustainably.
\end{abstract}

\subsection{Introduction}


Solid Earth Discuss., https://doi.org/10.5194/se-2017-60

Manuscript under review for journal Solid Earth

Discussion started: 26 July 2017

(c) Author(s) 2017. CC BY 4.0 License.

Oil palm is the main agricultural commodity in Malaysia that has helped transform its growing economic development. The country, as the second world largest producer of palm oil after Indonesia, has most of its total planted area under matured palms. This shows how significant palm oil industry is to Malaysia, which is a leading exporter of palm oil, producing $26 \%$ of the global trade and $11 \%$ of oils and fat production to meet world demand (Malaysia Palm Oil Board, 2015). Presently, more than 5 million ha of land in the country is cultivated to oil palm, producing up to 17.73 million tonnes of palm oil and 2.13 million tonnes of palm kernel oil in a year.

The oil palm industry is rapidly expanding due to the increased demand for oil palm products, which is expected to drive oil palm cultivation to a projected worldwide area of about 38 million hectare by 2050 (Corley, 2009), making palm oil the dominant vegetable oil in the globe (Rajanaidul et al., 2000). This implies a need for a higher degree of efficiency in the production of the commodity to meet its increasing demand at the marketplace.

In Malaysia, one of the major constraints to land use efficiency in oil palm cultivation is the infertile nature of her soils. Due to this reason, research and development on the methods of alleviating the problems related to soil fertility is essential for successful oil palm production. Oil palm in Peninsular Malaysia is mostly cultivated on soils classified as Ultisols (Soil Survey Staff, 2014), which is one of the most common soil Order in the tropics. These soils are highly weathered, having nutrients insufficient for sustainable production of oil palm unless they are fertilized (Shamshuddin et al., 2015).

Due to close proximity to the Equator, tropical regions are subjected to intense rainfall and high temperature throughout the year. Because of this, the cation exchange capacity is low, resulting in the low availability of basic cations that limit oil palm production (Paramananthan, 2003). Additionally, Ultisols are acidic in nature, but oil palm is considered as acid-tolerant (Shamshuddin and Auxtero, 1991). The characteristically low $\mathrm{pH}$ of Ultisol is due to the presence of soluble aluminum, which may affect the growth of oil palm.

The soils are known to be dominated by secondary minerals such as kaolinite, gibbsite, goethite and hematite in the clay fraction (Shamshuddin and Ismail, 1995). This mineral assemblage forms the clay fraction that provides negative and positive charge in the soils (Palm et al., 2007). Soil mineralogy has been found to strongly influence soil fertility (Shamshuddin et al., 2015).

For about 100 years, Ultisols in Peninsular Malaysia have been utilized successfully for oil palm cultivation despite its low native fertility following appropriate agronomic management practices, with adequate fertilization and conservation practices (Goh et al., 2008). Oil palm 
Solid Earth Discuss., https://doi.org/10.5194/se-2017-60

Manuscript under review for journal Solid Earth

Discussion started: 26 July 2017

(c) Author(s) 2017. CC BY 4.0 License.

is known to be acid-tolerant although it can grow better if soil $\mathrm{pH}$ is raised to an acceptable level that reduces exchangeable aluminum (Shamshuddin et al., 2015).

A proper soil survey and characterization of an area allocated to oil palm cultivation would provide vital information on its suitability. A study was therefore conducted to determine the formation and physico-chemical properties of an Ultisol cultivated to oil palm in Bera, Peninsular Malaysia. Based on the available data from the study, the soil was evaluated for its suitability for sustainable oil palm cultivation.

\subsection{Materials and Methods}

\subsection{The study area and soil sampling}

The study was conducted in an oil palm plantation belonging to a farmer in Bera, Pahang (GPS 03.27362 N, 102.58044 E). Mapping of the area under investigation was carried out by conventional soil survey techniques, using soil auger to collect samples at pre-determined spots at short distance from each other. Soil color and texture (using finger) were immediately determined. Selected soil samples were subjected to mechanical analysis in the laboratory at Univesiti Putra Malaysia, Serdang, for the determination of particle-size distribution.

Based on color and texture, it was concluded that the area under investigation comprised only one soil type, evenly distributed throughout the oil palm plantation. Then, a soil pit was dug at an appropriate location in the plantation to study its profile in detail. The pedogenetic horizons in the soil profile were identified and subsequently described, followed by collecting soil samples according to the genetic horizons so identified. The samples were brought to the laboratory in Universiti Putra Malaysia at Serdang in preparation for the detailed soil analyses.

Note that the soil in the area was completely weathered at least up to 2 meters depth due to very long exposure to the tropical conditions prevailing in Peninsular Malaysia. As such, the rock outcrops that formed the soil were not able to be identified during the soil survey. However, the rock type forming the soil in the area was later determined using a geology map produced by Mohd Shafeea et al. (2000), which is shown in Figure 1. 
Solid Earth Discuss., https://doi.org/10.5194/se-2017-60

Manuscript under review for journal Solid Earth

Discussion started: 26 July 2017

(C) Author(s) 2017. CC BY 4.0 License.

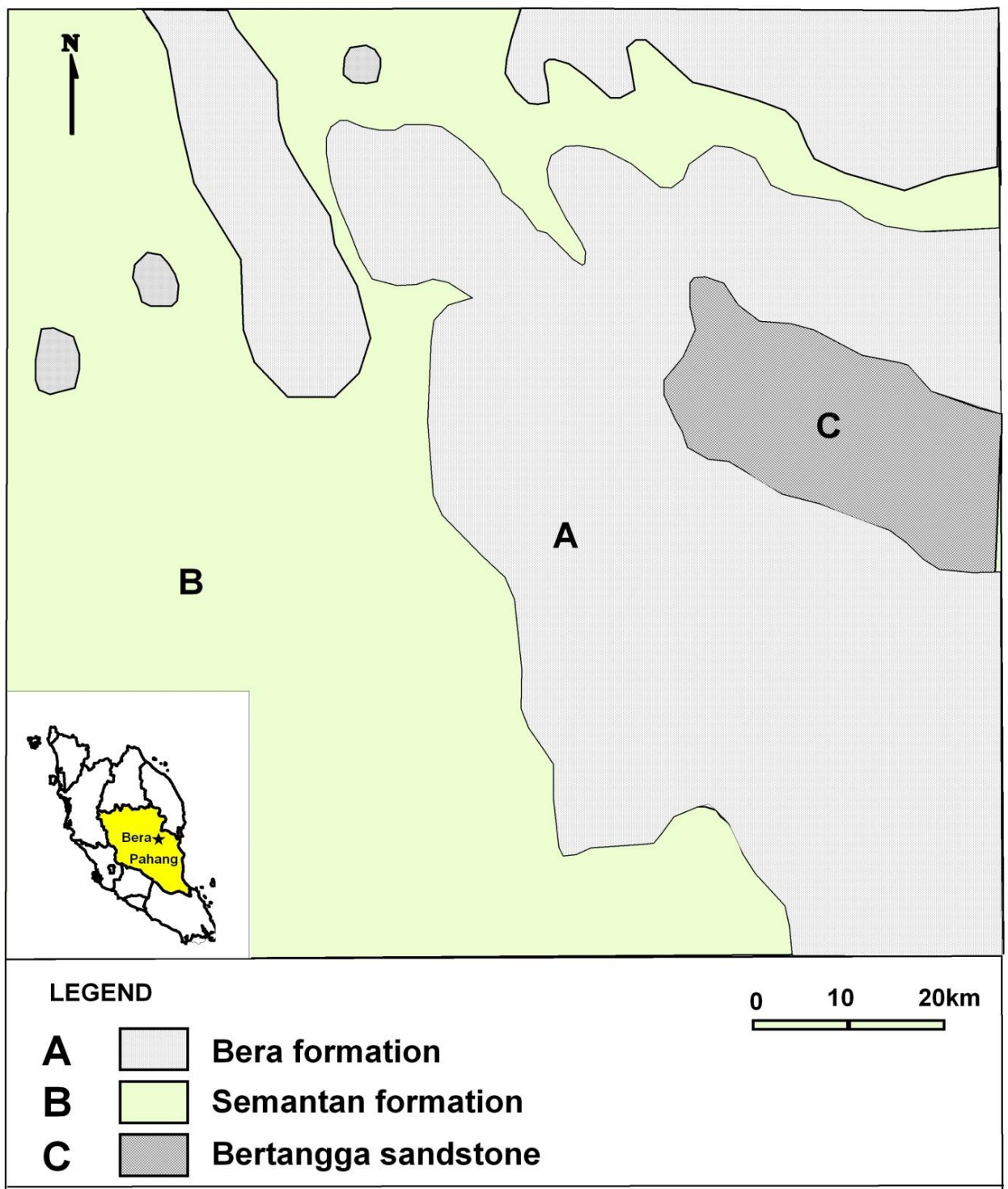

Figure 1. The geology map of Bera area (indicated by the star), Pahang (shown in yellow), Peninsular Malaysia (modified from Mohd Shafeea et al., 2000)

( $\mathrm{A}=$ Bera Formation; $\mathrm{B}=$ Semantan Formation; $\mathrm{C}=$ Sandstone $)$ 
Solid Earth Discuss., https://doi.org/10.5194/se-2017-60

Manuscript under review for journal Solid Earth

Discussion started: 26 July 2017

(c) Author(s) 2017. CC BY 4.0 License.

\subsection{Particle-size analysis}

Soil particle-size distribution was carried out using the pipette method. The textural classification was based on USDA soil texture triangle of size classes as clay $(<2 \mu \mathrm{m})$, silt $(2$ $50 \mu \mathrm{m})$ and sand as (50-2000 $\mu \mathrm{m})$ (Soil Survey Staff, 2014).

\subsection{Chemical analyses}

Soil $\mathrm{pH}$ was determined in water at a soil to solution ratio of 1:2.5 (Jones jr, 2002). The electrical conductivity (EC) was measured in water at a soil to solution ratio of 1:5. Exchangeable cations were extracted using $100 \mathrm{~mL}$ of $1 \mathrm{M}$ ammonium acetate buffered at $\mathrm{pH}$ 7. The concentrations of $\mathrm{K}, \mathrm{Ca}, \mathrm{Mg}$ and $\mathrm{Na}$ in the solutions were determined by the atomic absorption spectrophotometer (AAS) (Ross and Ketterings 1995; Shamshuddin, 2006). Cation exchange capacity (CEC) was determined by leaching the ammonium ions from the exchange sites with $0.05 \mathrm{M} \mathrm{K}_{2} \mathrm{SO}_{4}$ after the soil was leached for the exchangeable cations extraction and the CEC from the extract was determined using an auto analyzer. Prior to that, the soil was washed with $100 \mathrm{~mL}$ of ethanol (95\%) to remove excess $\mathrm{NH}_{4}{ }^{+}$(Jackson, 2005). Total carbon in soil was determined by Dry Combustion techniques using LECO CR-412 carbon analyzer (LECO, corporation. St. Joseph, USA) by weighing one gram of soil into a tarred ceramic boat. Available phosphorus was analyzed using Bray and Kurtz II method (Landon, 2014). In this method, 2 grams of soil was put in a $50 \mathrm{~mL}$ volumetric flask and 14 $\mathrm{mL}$ of extracting solution $\left(0.03 \mathrm{~N} \mathrm{NH} \mathrm{NH}_{4}\right.$ and $\left.0.1 \mathrm{M} \mathrm{HCl}\right)$. Using the wrist inversion techniques, the mixture was inverted for 45 seconds and the extract was filtered using the Whatman no.42 filter paper.

Exchangeable $\mathrm{Al}$ was extracted using $1 \mathrm{M} \mathrm{KCl}$ (Elisa et al., 2015) and $\mathrm{Al}$ in the extract was measured using an inductively coupled plasma optical emission spectrometry (ICP-OES). Fifty $\mathrm{mL}$ of $1 \mathrm{M} \mathrm{KCl}$ was added into a $5 \mathrm{~g}$ soil in a plastic vial. This was agitated for 30 minutes and the supernatant was decanted using the Whatman no. 42 filter paper. Total micronutrients content of the soil was extracted using Aqua Regia method (Gray et al., 2006) and the elements in the solutions were determined using AAS. 
Solid Earth Discuss., https://doi.org/10.5194/se-2017-60

Manuscript under review for journal Solid Earth

Discussion started: 26 July 2017

(c) Author(s) 2017. CC BY 4.0 License.

\subsection{X-Ray Diffraction analysis}

$\mathrm{XRD}$ analysis was performed to determine the clay mineralogical composition. During mechanical analysis, when soil was separated into sand, silt and clay after organic matter in the soil has been removed through the action of hydrogen peroxide. The clay was collected, spread on a slide and run on Philip PW 3040/60 X'pert Pro X-ray diffractometer at room temperature (Shamshuddin, 2011), using CuK-alpha radiation target, operated at $40 \mathrm{kV}$ and $30 \mathrm{~mA}$. The oriented specimens were scanned from 3 to $50^{\circ} 2 \theta$ at $1^{\circ}$ per minute.

\subsection{Results and Discussion}

\subsection{The geology of the area}

The geology of the area under investigation is depicted in Figure 1 based on the study of Shafeea et al. (2000) who found that Bera area in Pahang was composed mainly of three rock types: 1) Bera Formation; 2) Semantan Formation, and 3) Berangga Sandstone. The soil of the area under study was formed from rocks of Bera Formation of Middle Permian age.

These rocks of Bera Formation consisted predominantly of clastic rocks, including mudstone, shale, sandstone and siltstone mixed with tuffaceous materials. These rocks were partly exposed and/or subjected to several degrees of metamorphism during the history of their existence since Permian era.

The oil palm plantation where the study was conducted happened to be located in the area dominated by fine-grained materials on the basis of the clayey nature of the soils so formed; most probably they were mudstone and shale mixed with tuffs having high amount of oxides of Fe. Such being the case, the color of the soil was reddish in nature. If the parent materials of the soil were partly composed of coarse-grained rocks, such as clastic rocks and/or sandstone, the amount of sand in the soil would have been much higher than that reported in this study.

\subsection{Morphological properties of the soil}

The area under investigation was an oil plantation (Figure 2) which was used for a field trial for oil palm by another group of researchers and the results of which will be published 
Solid Earth Discuss., https://doi.org/10.5194/se-2017-60

Manuscript under review for journal Solid Earth

Discussion started: 26 July 2017

(c) Author(s) 2017. CC BY 4.0 License.

elsewhere. The numerals shown in the diagrammatic representation of the experimental plot (Figure 3) were the treatment blocks of the said field trial. It was observed that the palm grew quite well and the yield (in terms of fresh fruit bunches) was above the Malaysian average of about 30 t/ha/year (Figure 2), which was considered high.

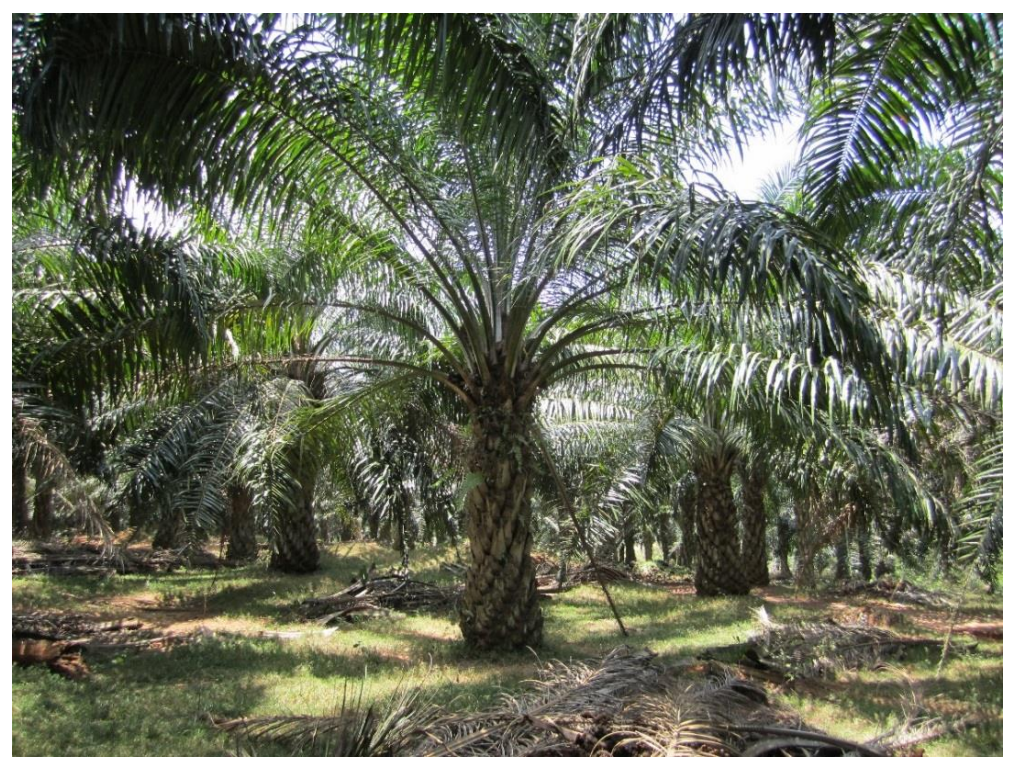

Figure 2. Oil palm in the plantation in the study area

The current paper is the result of the investigation mainly on the physico-chemical properties of the soil in the field trial. The other objective of the study was to explain the genesis of the soils formed on fine-grained sedimentary mixed with tuffs in geological time. After a long period of intense weathering under tropical conditions, the soil so formed was dominated by secondary minerals of low fertility status. Yet, the yield of the oil palm grown on the soil was high, comparable to that of the other parts of the country. We intend to find out why and how the oil palm performs so well in spite of the fact that the soil is inherently poor in fertility. 
Solid Earth Discuss., https://doi.org/10.5194/se-2017-60

Manuscript under review for journal Solid Earth

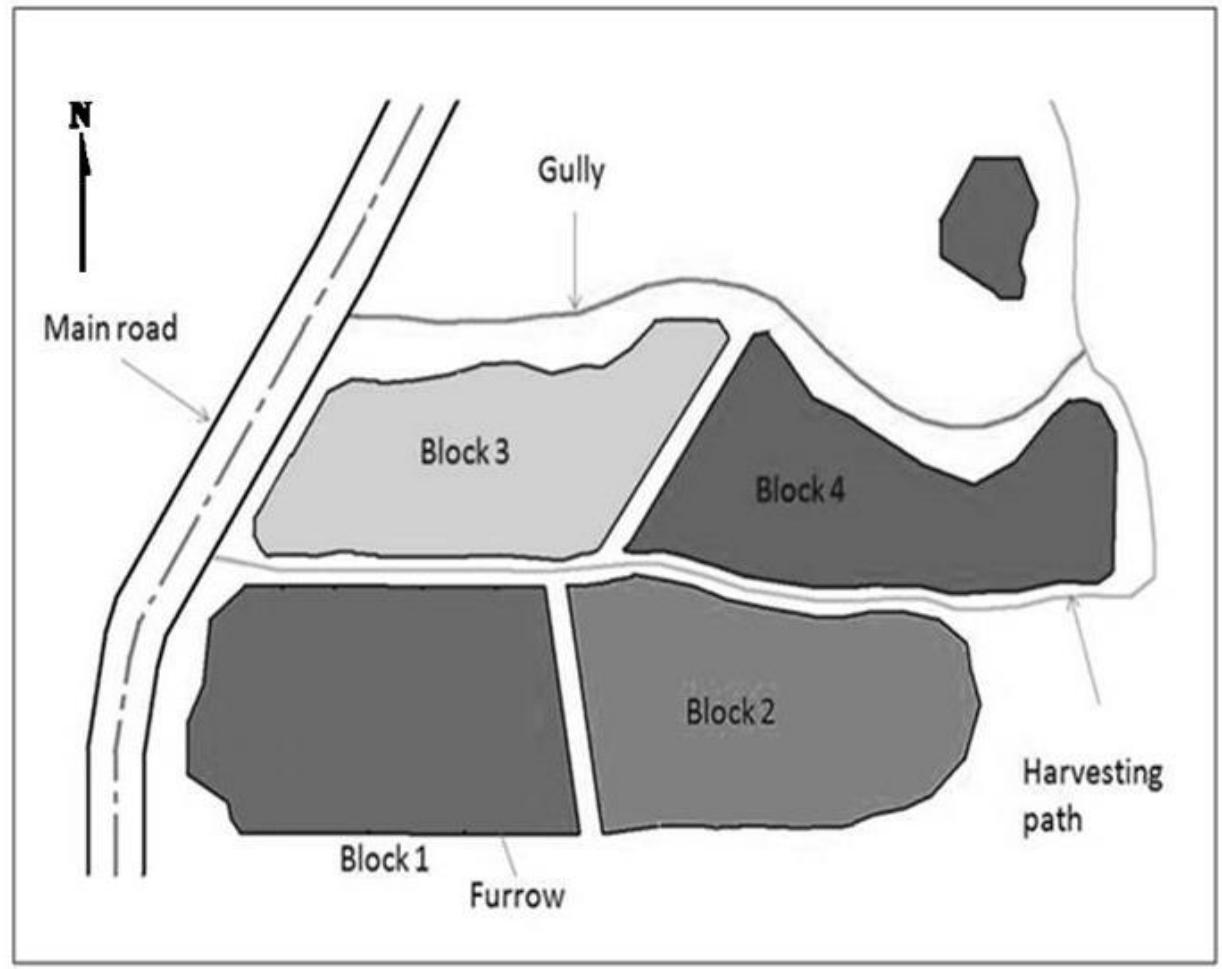

Figure 3. Diagramatic representation of the experimental plots in the area under study in

$$
\text { Bera, Pahang }
$$

Morphological characterization of the soil profile in the field showed the presence of an argillic horizon $(\mathrm{Bt})$, evidenced by the presence of patchy cutans in the subsoil (Table 1; Figure 4), and was confirmed by the accumulation of clay at depth (Table 2). On checking the soil profile in detail, we found that the boundaries demarcating the genetic horizons were diffused, making it difficult to distinguish between them (Table 1). The topsoil has a strong brown color (7.5YR 4/6), which changed to yellowish red (5YR 6/8) in the subsoil. Lower down the profile, the soil color was red 2.5YR4/6. Reddish soil color was indicative of the presence of hematite $\left(\mathrm{Fe}_{2} \mathrm{O}_{3}\right)$. The soil structure was sub-angular blocky and root abundance decreased down the soil profile.

The soil was moderately drained, probably due to the presence of too much clay throughout the depth of the soil profile. Had there been more sand present in the soil, the drainage class would have been well-drained. The organic matter content of in topsoil was very high, 
Solid Earth Discuss., https://doi.org/10.5194/se-2017-60

Manuscript under review for journal Solid Earth

Discussion started: 26 July 2017

(c) Author(s) 2017. CC BY 4.0 License.

probably due to the debris from fallen fronds and/or empty fruit bunches which had been laid out in the inter-row of the oil palm. High organic matter in the topsoil could have resulted in soil structural improvement which, to a certain extent, had enhanced soil fertility.

Table 1: Description of the soil profile

\begin{tabular}{|c|c|c|}
\hline Horizon & Depth & Description \\
\hline & $0-18 \mathrm{~cm}$ & $\begin{array}{l}\text { Strong brown (7.5YR 4/6); clay; moderate, } \\
\text { sub-angular blocky; friable; many coarse } \\
\text { roots; clear, smooth boundary; }\end{array}$ \\
\hline $\mathrm{Bt}_{1}$ & $18-57 \mathrm{~cm}$ & $\begin{array}{l}\text { Yellowish red (5YR 5/8); clay; moderate, } \\
\text { sub-angular blocky; friable; thin, patchy } \\
\text { cutans; many course roots; diffuse, smooth } \\
\text { boundary; }\end{array}$ \\
\hline $\mathrm{Bt}_{2}$ & $57-85 \mathrm{~cm}$ & $\begin{array}{l}\text { Red ( } 2.5 \text { YR 4/6); clay; moderate, sub-angular } \\
\text { blocky; friable; thin, patchy } \\
\text { cutans; few coarse roots; , diffuse, smooth } \\
\text { boundary. }\end{array}$ \\
\hline $\mathrm{Bt}_{3}$ & $85-146 \mathrm{~cm}$ & $\begin{array}{l}\text { Red ( } 2.5 \text { YR 4/6); clay; moderate, sub-angular } \\
\text { blocky; friable; thin patchy cutans; few } \\
\text { course root; diffuse, smooth boundary. }\end{array}$ \\
\hline
\end{tabular}


Solid Earth Discuss., https://doi.org/10.5194/se-2017-60

Manuscript under review for journal Solid Earth

Discussion started: 26 July 2017

(c) Author(s) 2017. CC BY 4.0 License.

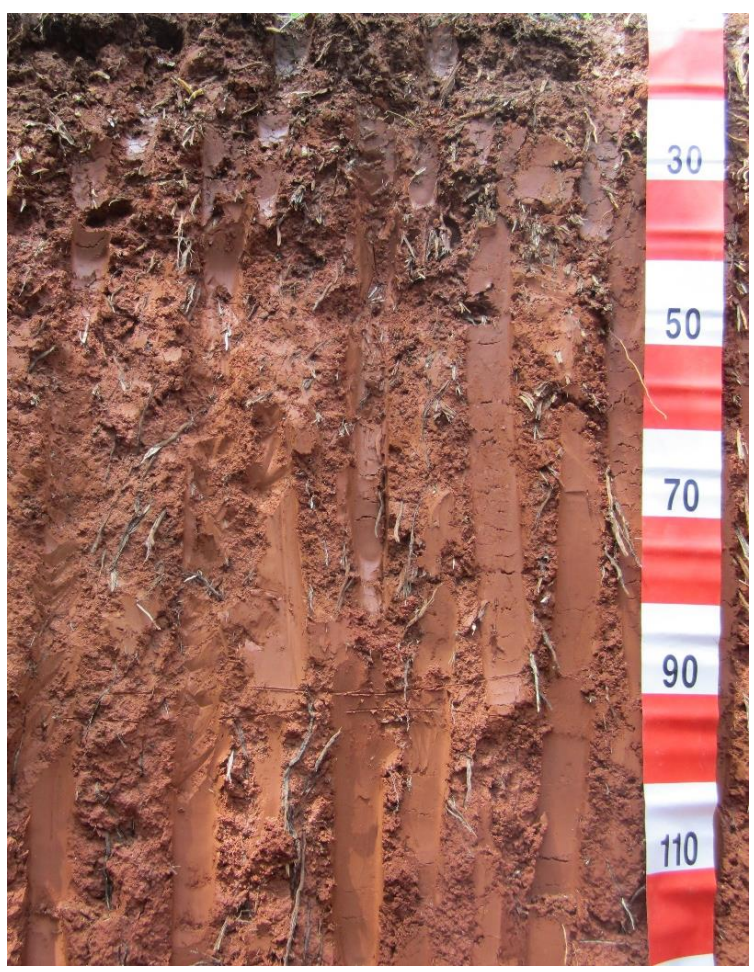

Figure 4. The profile of Jempol Series

Table 2: Particle-size distribution of the soil under study

\begin{tabular}{clllll}
\hline Horizon & Depth $(\mathrm{cm})$ & Sand $(\%)$ & Silt $(\%)$ & Clay $(\%)$ & Texture \\
\hline $\mathrm{Ap}_{1}$ & $0-18$ & 7.34 & 14.88 & 75.78 & Clay \\
$\mathrm{Bt}_{1}$ & $18-57$ & 4.03 & 9.39 & 84.58 & Clay \\
$\mathrm{Bt}_{2}$ & $57-85$ & 3.87 & 7.63 & 88.05 & Clay \\
$\mathrm{Bt}_{3}$ & $85-146$ & 5.08 & 9.49 & 84.43 & Clay \\
\hline
\end{tabular}

The soil can be classified as Jempol Series based on the criteria set by the System of Soil Classification in Peninsular Malaysia (Paramananthan, 1987). According to Tessens and Shamshuddin (1983), this soil series was formed on sedimentary and/or metamorphic rocks mixed with tuffs. Further, the researchers classified the soil of Jempol Series found in Pahang some $50 \mathrm{~km}$ away from the site of the current study (Bera) as an Ultisol with low fertility. 
Solid Earth Discuss., https://doi.org/10.5194/se-2017-60

Manuscript under review for journal Solid Earth

Discussion started: 26 July 2017

(c) Author(s) 2017. CC BY 4.0 License.

\subsection{Mineralogy of the clay fraction}

The XRD pattern of the clay fractions of the soil from all genetic horizons clearly indicated the mineralogical composition of the soil. Kaolinite was found to be the most abundant clay mineral in the studied soil (Figure 5). Goethite and hematite were also found in the soil, explaining its reddish to yellowish coloration. The X-ray diffractograms showed peaks at 7.2 and $3.59 \AA$ (kaolinite), 2.69 (hematite) and $4.19 \AA$ (goethite) in the Ap horizon, proving the presence of the minerals so mentioned. The same mineralogical assemblage occurs in the genetic horizons of the subsoil. The presence of these minerals might have resulted in the phenomenon of low CEC, which somewhat reduced soil productivity by way of low cations retention. The presence of the mentioned minerals in the Ultisol under study is consistent with that found by the previous studies of Tessens and Shamshuddin (1983) and Shamshuddin and Fauziah (2010). Knowing the mineralogical assemblage of the clay fraction of the soil is crucial in assessing the important physical and chemical properties related to the growth of oil palm.

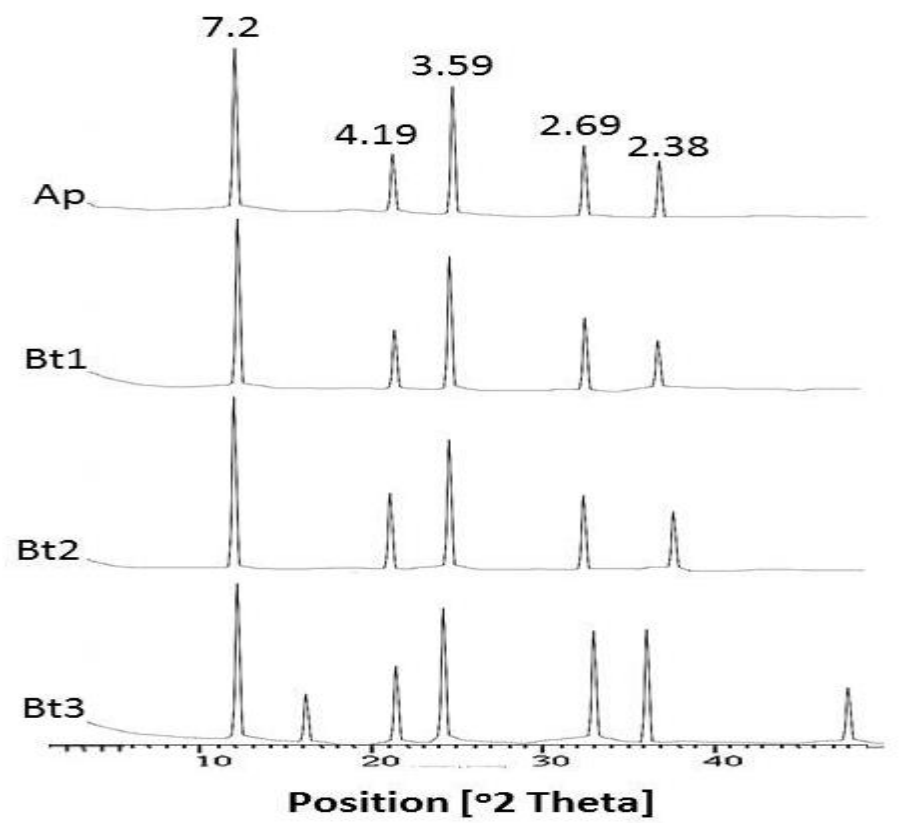

Figure 5. XRD diffraction patterns of oriented clays from the various horizons of the studied soil 
Solid Earth Discuss., https://doi.org/10.5194/se-2017-60

Manuscript under review for journal Solid Earth

Discussion started: 26 July 2017

(c) Author(s) 2017. CC BY 4.0 License.

\subsection{Physico-chemical characteristics of the soil}

The soil under study was Jempol series, which was dominated by the clay fraction in all the genetic horizons, having more than $75 \%$ clay content (Table 2 ). As such, the texture of all horizons was clay. Soils, which are clayey in nature, are thought to originate mainly from fine-grained rocks, such as shale, which was consistent with the study of Reineck and Singh (1973).

The occurrence of patchy cutans (Table 1) observed in the subsoil during the field work was indicative of the presence of argillic horizon $(\mathrm{Bt})$. The clay content was the highest in the $\mathrm{Bt}_{2}$ horizon, proving yet again that there was clay accumulation in that zone. The increase in the clay content with depth is thought to be a result of the translocation/illuviation of the clay in the soil during its formation (Hattori et al., 2005). Due to low basic cations together with low CEC, it was confirmed that the soil was an Ultisol as defined by Soil Taxonomy (Soil Survey Staff, 2014).

High clay content in the soil means that water movement down the soil profile is somewhat restricted. Nonetheless, this is not expected to affect the growth of oil palm significantly as the crop can grow even in the swampy areas.

Soil structures of the topsoil were found to be good, probably due to the presence of sufficient amount of organic matter in that zone. Hence, oil palm roots can penetrate the soil profile down to 1 meter depth easily, in the process of seeking for water, especially during dry period (Figure 4). This was confirmed by the presence of some coarse roots at the depth of $85 \mathrm{~cm}$ and even below this; the rooting depth of oil palm is normally $30 \mathrm{~cm}$ (Tinker and Nye, 2000). Oil palm roots were mainly confined to the topsoil (Figure 4). Note that the roots occurring below $40 \mathrm{~cm}$ depth were mostly the coarse ones. This means than that oil palm is a surface feeder, getting its nutrients mainly by the fine roots existing in the topsoil.

The soils collected from the four genetic horizons have a slightly acidic reaction in water (Table 3); soil pH obtained by the current study was typical of a Malaysian Ultisol, having some soluble aluminum in the soil solution, thereby causing a decrease in soil $\mathrm{pH}$ (Shamshuddin and Fauziah, 2010). Figure 6 shows the relationship between soil pH and exchangeable Al. As the exchangeable Al in the soil increased, soil pH decreased. This phenomenon can be explained by the hydrolysis of $\mathrm{Al}^{3+}$ in the soil solution. The reaction can be depicted as follows:

$$
\mathrm{Al}^{3+} \cdot 6 \mathrm{H}_{2} \mathrm{O}+\mathrm{H}_{2} \mathrm{O}=\mathrm{Al}^{2+} \mathrm{OH} .5 \mathrm{H}_{2} \mathrm{O}+\mathrm{H}_{3} \mathrm{O}
$$


Solid Earth Discuss., https://doi.org/10.5194/se-2017-60

Manuscript under review for journal Solid Earth

Discussion started: 26 July 2017

(c) Author(s) 2017. CC BY 4.0 License.

Table 3: Chemical properties of Jempol Series

\begin{tabular}{lllllll}
\hline Horizon & Depth $(\mathrm{cm})$ & $\mathrm{pH} \mathrm{H}_{2} \mathrm{O}$ & $\mathrm{EC}(\mathrm{dS} / \mathrm{m})$ & Total C (\%) & Total N (\%) & $\begin{array}{l}\text { Available } \\
\text { P mg kg- }\end{array}$ \\
\hline Ap & $0-18$ & 4.92 & 0.13 & 1.05 & 0.13 & 3.92 \\
$\mathrm{Bt} 1$ & $18-57$ & 4.62 & 0.07 & 0.77 & 0.12 & 2.30 \\
$\mathrm{Bt} 2$ & $57-85$ & 4.09 & 0.15 & 0.27 & 0.08 & 2.98 \\
$\mathrm{Bt} 3$ & $85-146$ & 3.66 & 0.22 & 2.60 & 0.26 & 2.23 \\
\hline
\end{tabular}

As the $\mathrm{pKa}$ of $\mathrm{Al}$ is 5 , soil solution $\mathrm{pH}$ will go towards the value of 5 to achieve the state of equilibrium. Additionally, if sufficient amount of $\mathrm{Fe}^{3+}$ is present, solution $\mathrm{pH}$ will then be going towards 3 because the pKa of Fe is 3 (Shamshuddin et al., 2015). In the end, the equilibrium soil solution $\mathrm{pH}$ is somewhere between 3 and 5. This is the reason why the $\mathrm{pH}$ of highly weathered Peninsular Malaysian soils is about 4.5 on the average (Shamshuddin and Fauziah, 2010). As such, the pH of the soil under study was 3.7-4.9 (Table 3).

Reverse reaction can also occur if soil $\mathrm{pH}$ is increased due to soil management practices. This happens when ammonium sulfate is applied continuously onto the soil to supply nitrogen to fulfill the requirement oil palm growth in order to sustain production. This phenomenon occurs due to specific adsorption of $\mathrm{SO}_{4}{ }^{2-}$ onto the oxide of $\mathrm{Fe}$ in the soil (Shamshuddin et al., 2015). For the soil under study, it is hematite $\left(\mathrm{Fe}_{2} \mathrm{O}_{3}\right)$ that could play the role of the $\mathrm{Fe}$ oxide so mentioned.

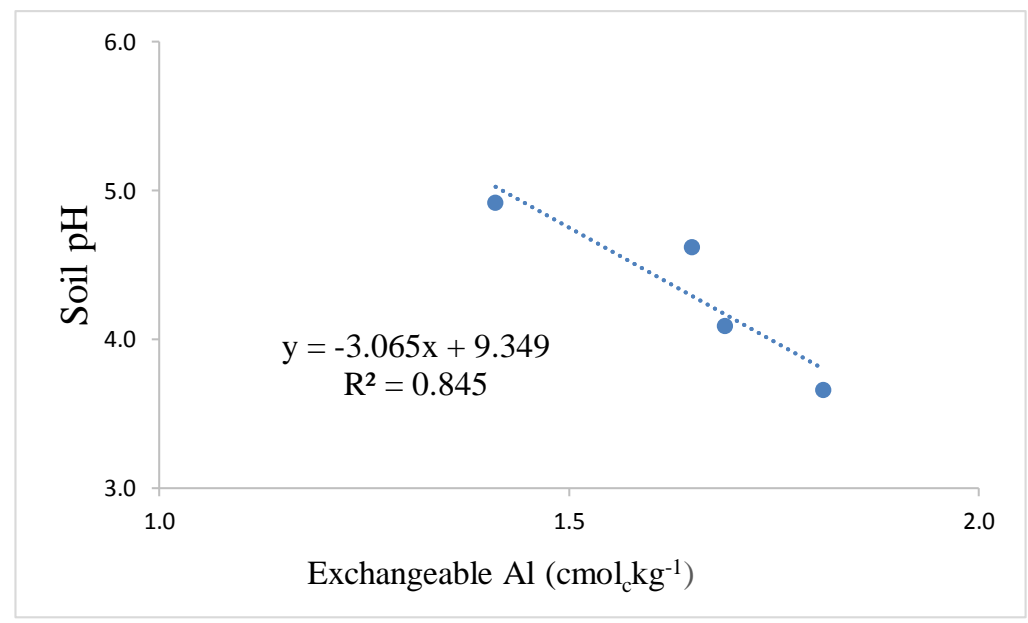

Figure 6. Relationship between soil $\mathrm{pH}$ and exchangeable $\mathrm{Al}$ 
Solid Earth Discuss., https://doi.org/10.5194/se-2017-60

Manuscript under review for journal Solid Earth

Discussion started: 26 July 2017

(c) Author(s) 2017. CC BY 4.0 License.

Aluminum in the soil solution of Ultisols in Malaysia is often present at a toxic level for some crops (Shamshuddin et al., 2015). If soil $\mathrm{pH}$ is increased to a level above 5, Al will be precipitated as inert Al-hydroxides (as explained by the equation on Al hydrolysis given earlier); thus, no longer causing any problem to the roots of the oil palm growing on the plantation. It is a good agronomic practice to increase soil $\mathrm{pH}$ to a level above 5. However, liming to increase soil $\mathrm{pH}$ to sustain production is not recommended because it is too costly due to the large area being cropped to oil palm in the country. For the soil under study, soil pH was slightly below 5 in topsoil, with values decreasing with depth (Table 3 ).

Chemical analyses of soil samples showed that the exchangeable bases were within the acceptable range (Table 3) and likewise the CEC was within the range expected for a typically highly weathered soil in the tropics (Table 4). High organic matter content as reflected by the high nitrogen and carbon content in the topsoil is thought to be due to the felled fronds and empty fruit bunches that were previously applied in the inter-rows of the oil palm. The amount of carbon and nitrogen was sufficient for the growth of oil palm in the plantation as reflected by the high yield obtained. Micronutrient contents ( $\mathrm{Mn}$ and $\mathrm{Zn}$ ) in the soil are sufficient for the requirement of oil palm growth to sustain normal production (Table 5).

Table 4: Exchangeable cations and CEC of Jempol Series

\begin{tabular}{|c|c|c|c|c|c|c|}
\hline Horizon & $\mathrm{Ca}$ & $\mathrm{Mg}$ & $\begin{array}{c}\mathrm{K} \\
\text { mol }_{\mathrm{c}} \mathrm{kg}\end{array}$ & $\mathrm{Na}$ & $\mathrm{Al}$ & CEC \\
\hline Ap & 0.64 & 0.23 & 0.13 & 0.04 & 1.41 & 7.11 \\
\hline Bt1 & 0.44 & 0.15 & 0.19 & 0.04 & 1.65 & 5.7 \\
\hline $\mathrm{Bt} 2$ & 0.83 & 0.46 & 0.08 & 0.04 & 1.67 & 5.78 \\
\hline $\mathrm{Bt} 3$ & 1.56 & 1.66 & 0.15 & 0.04 & 1.81 & 10.1 \\
\hline
\end{tabular}

Table 5: Micronutrient contents in the soil of Jempol Series

\begin{tabular}{llll}
\hline $\mathrm{Cu}$ & $\mathrm{Fe}$ & $\mathrm{Mn}$ & $\mathrm{Zn}$ \\
\hline 64.5 & $\mathrm{mg} / \mathrm{kg}$ & & \\
63.4 & 7152.2 & 283.5 & 67.7 \\
62.1 & 7123.5 & 274.5 & 55.8 \\
50.5 & 7163.3 & 266.1 & 57.4 \\
\hline
\end{tabular}


Solid Earth Discuss., https://doi.org/10.5194/se-2017-60

Manuscript under review for journal Solid Earth

Discussion started: 26 July 2017

(c) Author(s) 2017. CC BY 4.0 License.

The available phosphorus in the soil was low (Table 3). However, the low level of available $\mathrm{P}$ in the soil was not reflected by the yield of the oil palm in terms of fresh fruit bunches. The oil palm in the plantation under study was reported by the owner to produce among the highest yield in the area. This was, perhaps, due to the proper agronomic management by its owner which had applied fertilizer regularly at the time when it was needed. Low $\mathrm{P}$ availability in the soil could be due to immobilization via specific adsorption of the nutrient by $\mathrm{Fe}$ and/or Al, forming Fe-P and Al-P compound (Fageria, and Baligar, 2008). Iron content in the soil was found to be high (Table 5), which was reflected by its reddish color. XRD analysis shown in Figure 5 proved the presence of reddish hematite $\left(\mathrm{Fe}_{2} \mathrm{O}_{3}\right)$ as well as goethite $(\mathrm{FeOOH})$.

\subsection{Soil genesis and classification}

To understand the formation of the soil, its profile description was studied in detail. This was followed by studying the physico-chemical properties of the soil obtained from laboratory analyses. Besides, the geology of the area had to be understood so that rocks forming the soil were identified. We believed that the soil formed from fine-grained sedimentary rocks mixed with tuffs of very old age (Permian). These rocks were subjected to a very long process of weathering under tropical conditions, resulting in the development of a very deep soil. Due to the prevailing high temperature and rainfall, the soil had adequate moisture throughout the year. This condition is referred to as the udic moisture regime (Soil Survey Staff, 2014). In the end, the mineralogy of the soil would be dominated by the secondary minerals, such as kaolinite and the oxides of $\mathrm{Fe}$ and $\mathrm{Al}$, which had far reaching consequences on the inherent fertility of the soil.

The topsoil was yellowish red, which becoming redder with depth. This was probably due to the presence of higher amount of hematite in the subsoil compared to that of the subsoil. Hematite is a very common mineral in the highly weathered and well-drained soil of Peninsular Malaysia (Shamshuddin et al., 2004). The presence of this mineral was confirmed by XRD analysis.

We are convinced that the soil had an argillic horizon evidenced by the occurrence of the patchy cutans in the subsoil. This phenomenon always occurs in the subsoil of Ultisols in Peninsular Malaysia (Shamshuddin and Fauziah, 2010). The evidence for the occurrence of the argillic horizon was supported by the significant increase in the clay content in the $\mathrm{Bt}_{2}$ horizon. As such, the subsoil is qualified to be called as an argillic horizon. 
Solid Earth Discuss., https://doi.org/10.5194/se-2017-60

Manuscript under review for journal Solid Earth

Discussion started: 26 July 2017

(c) Author(s) 2017. CC BY 4.0 License.

The CEC of the soil was rather low. This low value of CEC is associated with the dominant presence low activity clay such as kaolinite. The presence of gibbsite, hematite, and goethite further contributed to the low CEC value. Low basic cations in the soil were related very much to the low CEC. Under strongly leaching environment prevailing in the soil, much of the basic cations were lost to the underground water during rainy season. Using the available data such as diagnostic horizon (Bt), CEC, cations and other, the soil can be classified according to Soil Taxonomy (Soil Survey Staff, 2014). Based on the system, the soil was classified as clayey, isohyperthermic family of Typic Paleudults.

\subsection{The suitability of the soil for oil palm cultivation}

Oil palm can be cultivated on a wide range of soils in the tropics (Hartley, 1988; Piggot, 1990; Sugandi, 2005). Furthermore, the growth, yield, and management of oil palm are greatly influenced by the soil type and climatic conditions of the area where oil palm is being cultivated (Goh and Chew, 1995; Paramananthan, 2000; Turner and Gillbanks, 2003). The agronomic parameters used to select suitable areas for oil palm cultivation are the soil properties related to growth limitations of oil palm (Wong, 2009) and the terrain of the growing areas as well as climatic requirement (Mantel et al., 2007). Matching available soil information with the requirement would produce a rating that indicates the capability of the land under study to support oil palm cultivation.

Oil palm is most suitable and commonly cultivated in humid tropical climatic regions where rain is abundant throughout the entire year (Corley and Tinker, 2003). The optimal yield per hectare of oil palm requires rainfall of 2500 to $3500 \mathrm{~mm}$ or more distributed evenly (IPI, 1991); thus, providing the soil with adequate moisture.

Bera, where the oil palm plantation was located, had a mean annual rainfall of 2000-2500 $\mathrm{mm} /$ year and a yearly temperature range of $25-30^{\circ} \mathrm{C}$. The relative humidity in the area was between $80-90 \%$. According to the Koppen-Greiger system, the area was classified as having a tropical rainforest climate (Af) (Malaysian Meteorological Department, 2016). The soil in the area under study had adequate moisture, having udic regime throughout the year (Hartley, 1988).

The terrain of the oil palm plantation under discussion was gently sloping. According to shamshuddin et al. (2015) this elevation was considered suitable for oil palm cultivation. The 
Solid Earth Discuss., https://doi.org/10.5194/se-2017-60

Manuscript under review for journal Solid Earth

Discussion started: 26 July 2017

(c) Author(s) 2017. CC BY 4.0 License.

soil was fine textured and so can retain sufficient moisture; thus, the drainage was excellent for oil palm cultivation. The soil was deep, moderately drained and having no stones or laterite in its profile. This indicates that root penetration into the soil is easy and as such oil palm grown on the soil will have good anchorage, high access to soil moisture with a high ability to exploit nutrients. Oil palm roots were even found at the depth of about $85 \mathrm{~cm}$ (Figure 4). The structures of the soil was sub-angular blocky; thus, it is physically suitable for cultivating oil palm.

Table 6 Criteria for assessing the severity of soil limitations for oil palm cultivation

\begin{tabular}{|c|c|c|c|c|}
\hline $\begin{array}{l}\text { Soil properties } \\
\text { limitation }\end{array}$ & Desirable range & Minor limitation & Serious limitation & Very serious \\
\hline Terrain $\left({ }^{\circ}\right)$ & $0-12$ & $12-16$ & $16-24$ & $>24$ \\
\hline $\begin{array}{l}\text { Effective soil } \\
\text { Depth }(\mathrm{cm})\end{array}$ & $>90$ & $60-90$ & $30-60$ & $<30$ \\
\hline Stoniness $(\%)$ & $0-5$ & $5-20$ & $20-40$ & $>40$ \\
\hline Texture & $\begin{array}{l}\text { sandy clay loam, } \\
\text { clay loam }\end{array}$ & $\begin{array}{l}\text { loam, } \\
\text { sandy loam }\end{array}$ & loamy sand & sand \\
\hline Structure & well developed & $\begin{array}{l}\text { moderately } \\
\text { developed }\end{array}$ & $\begin{array}{l}\text { very weak, } \\
\text { massive }\end{array}$ & structureless \\
\hline $\begin{array}{l}\text { Water table } \\
(\mathrm{cm})\end{array}$ & $75-90$ & $60-75$ & $30-60$ & $<30$ \\
\hline Soil $\mathrm{pH}$ & $>4.0$ & $3.5-4.0$ & $3.0-3.5$ & $<3.0$ \\
\hline
\end{tabular}

Source: Shamshuddin et al. (2015)

It was found that the topsoil $\mathrm{pH}$ was slightly below 5 (Table 3). Although the soil was acidic in nature, oil palm should be able to grow well as it is acid-tolerant; it can even survive at the $\mathrm{pH}$ of 4.3 (Auxtero and Shamshuddin, 1991). In terms of soil $\mathrm{pH}$, the soil is suitable for oil palm cultivation (Shamshuddin et al., 2015). The possible problem is the lack of nutrients in the soil, especially available $\mathrm{P}$ which has to be regularly applied (Mutert, 1999; Shamshuddin and Noordin, 2011). Having the properties mentioned above, we believed that the soil is suitable for oil palm cultivation. However, it needs to be regularly checked so that enough nutrients are present in the soil for sustainable oil palm production. 
Solid Earth Discuss., https://doi.org/10.5194/se-2017-60

Manuscript under review for journal Solid Earth

Discussion started: 26 July 2017

(c) Author(s) 2017. CC BY 4.0 License.

\subsection{Conclusions}

The soil in Bera, Peninsular Malaysia used for the current study can be classified as an Ultisol, evidenced by the occurrence of Bt diagnostic horizon. It was formed under tropical environment on fine-grained sedimentary rocks mixed with tuffs of Permian age, and due to very long exposure to high temperature and high rainfall, the soil was highly weathered. The mineralogy of the clay fraction of the soil was dominated by kaolinite, hematite, goethite and gibbsite. Because of this, the CEC and eventually basic cations were low. Additionally, soil reaction was acidic, with $\mathrm{pH}$ slightly below 5 . The above-mentioned properties were not expected to significantly affect the sustainable production of oil palm. The suitability of the area for oil palm cultivation is further evidenced by the presence of udic moisture regime throughout the year. Hence, the soil under study is suitable for oil palm cultivation provided proper agronomic management is practiced.

\section{References}

Anda, M., Shamshuddin, J., Fauziah, C.I and Syed Omar, S.R.: Mineralogy and factors controlling charge development of three Oxisols developed from different parent materials. Geoderma, 143, 153-167, 2008.

Auxtero, E. A., and Shamshuddin, J.: Growth of oil palm (Elaeis guineensis) seedlings on acid sulfate soils as affected by water regime and aluminum, Plant soil, 137,243-257, 1991.

Corley, R. H. V.: How much palm oil do we need? Environ. Sci. Policy 12: 134-139, 2009.

Corley, R. H. V. and Tinker, P. B.: Vegetative propagation and biotechnology. The oil palm, 4, 201-215, 2003.

Elisa, A. A., Ninomiya, S., Shamshuddin, J. and Roslan, I.: Alleviating aluminum toxicity in an acid sulfate soil from Peninsular Malaysia by calcium silicate application. Solid Earth 7, 367-374, doi: 10.5194/se-7-367-2016, 2016.

Fageria, N. K. and Baligar, V. C.: Ameliorating soil acidity of tropical Oxisols by liming for sustainable crop production. Advances in agronomy, 99, 345-399, 2008.

Goh, K. J. and Chew P. S.: Managing Soil for Plantation Tree Crops. Soils Survey and Management of Tropical Soils. Malaysian Society of Soil Science and Param Agric. Soil Survey. 228-256, 1995.

Goh, K.J. and Teo C.B.: Agronomic principle and practices for fertilizer management of oil palm. Agronomic principle and practices for fertilizer management of oil palm, Sibu, Serawak 157-210, 2008. 
Solid Earth Discuss., https://doi.org/10.5194/se-2017-60

Manuscript under review for journal Solid Earth

Discussion started: 26 July 2017

(c) Author(s) 2017. CC BY 4.0 License.

Gray, C. W., Dunham, S. J., Dennis, P. G., Zhao, F. J., and McGrath, S. P.: Field evaluation of in situ remediation of a heavy metal contaminated soil using lime and redmud. Environmental Pollution, 142(3), 530-539, 2006.

Hartley, C. W. S.: The botany of oil palm. In, The oil palm 3rd edition. Longman, London: 47-94, 1988.

Hattori, D., Sabang, J., Tanaka, S., Kedawang, J. J., Ninomiya, I., Sakurai, K.: Soil characteristics under three vegetation types associated with shifting cultivation in a mixed dipterocarp forest in Sarawak, Malaysia. Soil Sci. Plant Nutr. 51:231-241, 2005.

IPI.: Fertilizer for high yield and quality: The oil palm. International Potash Institute, Bern, Switzerland, 1991.

Jackson, M. L.: Soil chemical analysis: advanced course. UW-Madison Libraries Parallel Press; 2005.

Jones Jr, J. B. Agronomic handbook: management of crops, soils and their fertility. CRC press, 2002.

Landon, J. R.: Booker tropical soil manual: a handbook for soil survey and agricultural land evaluation in the tropics and subtropics. Routledge, 2014.

Malaysia Palm Oil Board.: Overview of the Malaysian oil palm industry 2015. [Online] http://bepi.mpob.gov.my/images/overview/Overview_of_Industry_2015.pdf .Browsed on Oct. 12, 2016.

Malaysian Meteorological Department.: (on line access on October, 2016) http://www.met.gov.my.

Mantel, S., Wösten, H. and J. Verhagen.: Biophysical land suitability for oil palm in Kalimantan, Indonesia. ISRIC-World Soil Information, 2007.

Mohd Shafeea, L., Kamal, R. M. and Sone, M.: On the New Permian Bera Formation from Bera District, Pahang, Malaysia. Proc. Annual Geological Conference., Penang. pp: 151-158, 2000.

Mutert, E.: Suitability of soils for oil palm in Southeast Asia. Better Crop Inter., 13, 36-38, 1999.

Palm, C., Sanchez, P., Ahamed, S. and Awiti, A. Soils: A contemporary perspective. Annu. Rev. Environ. Resour. 32, 99-129, 2007.

Paramananthan, S.: Field Legend for Soil Survey in Malaysia. UPM Press, Serdang. 1987.

Paramananthan, S.: Soil Requirement of Oil palm for High Yields. In Proceedings of Seminar on Managing Oil palm for High Yield: Agronomic Principles. Ed: Goh Kah Joo. Malaysian Society of Soil Science and Param Agricultural Soil Survey, p18-38, 2000.

Paramananthan, S.: Land Selection for Oil Palm. In: Fairhurst, T. and Hardter, R. (eds.) The Oil Palm. Management for Large and Sustainable Yields. Potash \& Phosphate Institute, International Potash Institute, Singapore, pp.27-57, 2003. 
Solid Earth Discuss., https://doi.org/10.5194/se-2017-60

Manuscript under review for journal Solid Earth

Discussion started: 26 July 2017

(c) Author(s) 2017. CC BY 4.0 License.

Piggot, C. J.: Growing oil palms: an illustrated guide. 152 pp, Malaysia, The Incorporated Society of Planters, 1990.

Rajanaidu, N., Kushairi, A., Rafii, M.., A, M.D., Maizura, I., Isa, Z. and Jalani, B.: Oil palm genetic resources and their utilization: A review, in: N, R., Ariffin, D. (Eds.), Proceedings of International Symposium on Oil Palm Genetic Resources and Their Utilization. MPOB, Kuala Lumpur, Malaysia, pp. 34-80, 2000.

Reineck, H. E. and Singh I. B.: Depositional Sedimentary Environments. With Reference to Terrigenous Clastics. Corrected Reprint of the First Edition. - With 579 figs., 25 tables, 439 pp. -Berlin, Heidelberg, New York: Springer Verlag. ISBN 3-540-07377-9. DM46, 1973.

Ross, D. S. and Ketterings, Q.: Recommended method for determining soil cation exchange capacity, Newark: College of Agriculture, University of Delware, 1995.

Shamshuddin, J.: Acid Sulphate Soil in Malaysia, UPM, Serdang, 2006.

Shamshuddin, J.: Methods in Soil Mineralogy. Universiti Putra Malaysia Press, 2011.

Shamshuddin, J. and Fauziah, C.I.: Weathered tropical soils: the Ultisols and Oxisols. UPM Press, Serdang, 2010.

Shamshuddin, J., and Ismail, H..: Reactions of ground magnesium limestone and gypsum in soils with variable-charge minerals. Soil Science Society of America Journal 59.1: 106, 1995.

Shamshuddin, J. and Noordin, W. D.: Classification and management of highly weathered soils in Malaysia for production of plantation crops. In: Burcu, E. and Zkaraova, G. (Eds.), Principle, Application and Assessment in Soil Science, published by Intech, Croatia, pp. 75-86. 2011.

Shamshuddin, J., Muhrizal, S., Fauziah, I. and Husni, M. H. A.: Effects of adding organic materials to an acid sulfate soil on the growth of cocoa (Theobroma cacao L.) seedlings. Science of the total environment, 323(1), 33-45, 2004.

Shamshuddin, J., Noordin, W. D., Roslan, I., Fauziah, C.I. and Panhwar, Q.A.: Ultisols and Oxisols: Enhancing their productivity for oil palm, rubber and cocoa cultivation. UPM Press, Serdang, 2015.

Soil Survey Staff.: Soil survey laboratory methods manual. Soil Survey Laboratory Investigations Report, (42), Washington, DC, 2014.

Sugandi, A.: Characterization, Classification and Suitability for Oil Palm of Some Common Soils in Tawau-Semporna Area, Sabah, Dissertation, Universiti Putra Malaysia, . 2005.

Tessens, E. and Shamshuddin, J.: Quantitative Relationship between Mineralogy and Properties of Tropical Soils. UPM Press, Serdang, 1983.

Tinker, P.B. and Nye, P. H.: Solute movement in the rhizosphere. Oxford University Press, 2000. 
Solid Earth Discuss., https://doi.org/10.5194/se-2017-60

Manuscript under review for journal Solid Earth

Discussion started: 26 July 2017

(c) Author(s) 2017. CC BY 4.0 License.

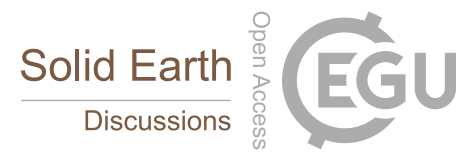

(c) (i)

Turner, P. D. and Gillbanks, R.A.: Soil, Climate and Their Effect on Yield. In: Oil Palm Cultivation and Management, $2^{\text {nd }}$ Edition. Incorporated Society of Planters, 2003.

Wong, I. F. T.: Soil-Crop Suitability Classification for Peninsular Malaysia, Department of Agriculture Malaysia, 2nd Edition. NO.BK 84/11.09/3R, 2009.

\section{ACKNOWLEDGEMENT}

We wish to express our sincere gratitude to Universiti Putra Malaysia and Lynas Corporation for the technical and financial supports during the conduct of the research. 